\title{
VIEŠŲJŲ PASLAUGŲ PRIEINAMUMAS SENIEMS ASMENIMS KAIMIŠKOSE VIETOVĖSE
}

\author{
Aušra Kavaliauskienė, Ilona Skridlaitė \\ Kauno kolegijos Medicinos fakulteto Socialinio darbo katedra
}

\begin{abstract}
Raktažodžiai:viešosios paslaugos, seni asmenys, kaimiška vietové, prieinamumas, eidžizmas (diskriminacija dẻl amžiaus).
\end{abstract}

\section{Santrauka}

Daugelis šalių susiduria su demografiniais pokyčiais, kai didejja senų žmonių skaičius, dèl to daugeliui senų žmonių reikalingos ịvairios paslaugos. Lietuvoje kaimiškose vietovèse (bendruomenèse) ypač daugèja senų žmonių. Gyventojams senejjant yra didesnis ịvairių paslaugų vietinèje bendruomenèje poreikis [15].

Viešoji paslauga - valstybės ar savivaldybių kontroliuojamų juridinių asmenų veikla teikiant asmenims socialines, švietimo, mokslo, kultūros, sporto ir kitas įstatymų numatytas paslaugas. LR ịstatymu nustatytais atvejais ir tvarka viešąsias paslaugas gali teikti ir kiti asmenys [16].

Vis tik tyrimai rodo, kad seni žmonès patiria socialinę izoliaciją (atskirtį). Šiuo atveju svarbų vaidmenị atlieka socialinè politika: turètų būti plètojama palaikanti ịvairių paslaugų infrastruktūra, bendruomenès ịtraukimas ir ryšiai, kurie sumažintų senų žmonių socialinès atskirties jausmą [5]. Pirmas palaikančios viešųų paslaugų infrastruktūros kūrimo etapas - paslaugu prieinamumo nustatymas, todèl svarbu išsiaiškinti pagrindinius paslaugu prieinamumui turinčius itakos veiksnius.

Šio straipsnio tikslas - atskleisti viešųjų paslaugu prieinamuma seniems asmenims kaimiškose vietovėse. Viešujų paslaugų - socialinių paslaugų, susisiekimo ir ryšių paslaugų, sveikatos apsaugos paslaugu - prieinamumas buvo analizuojamas taikant kokybini tyrimo metodą. Atliktas tyrimas atskleidè, kad viešųų paslaugų prieinamumą seniems asmenims kaimiškose vietovėse apriboja objektyvūs (sveikatos problemos, reikiamų paslaugų trūkumas, lëšų trūkumas reikiamoms paslaugoms, transporto pasiekiamumo problemos, gyvenimas geografiškai nepalankioje vietoveje) ir subjektyvūs (ịvairios baimès, nežinojimas, kad galima kreiptis ir gauti pagalbą, nenoras kreiptis dèl pagalbos) veiksniai. Viešųjų paslaugų prieinamumą seniems asmenims, gyvenantiems kaimiškose vietovėse, palengvina neformali kaimynų pagalba, giminių (vaikų) pagalba, neformali savanoriška specialistų pagalba bei asmens motyvacija pasirūpinti savimi.

\section{Ivadas}

Daugelis šalių susiduria su demografiniais pokyčiais, kai didejja ir didès senų žmonių skaičius, dèl to daugeliui senų žmonių reikalingos ịvairios paslaugos [7]. Kaimo bendruomenès yra teritorinès bendruomenès, kurių nariu tampama, pasirinkus gyvenamają vietą. Kaimo vietovėms būdinga: prastesnis kaimo socialinès infrastruktūros objektų aprūpinimas materialine - technine baze, daug žemesnè kaimo socialinès infrastruktūros paslaugas teikiančių darbuotojų kvalifikacija, specifinè kaimo vietovių apgyvendinimo sistema, kaimo gyventojų prisirišimas prie namų [1]. Kaimo gyventojams senėjant yra didesnis įvairių paslaugų vietinejje bendruomeneje poreikis [15].

Viešoji paslauga - valstybės ar savivaldybių kontroliuojamų juridinių asmenų veikla teikiant asmenims socialines, švietimo, mokslo, kultūros, sporto ir kitas įstatymų numatytas paslaugas. LR įstatymų nustatytais atvejais ir tvarka viešąsias paslaugas gali teikti ir kiti asmenys [16].

Vis tik tyrimai rodo, kad seni žmonès patiria socialinę atskirtį. Esant socialinei atskirčiai asmuo patiria minimalu socialinio dalyvavimo lygị [5].

Socialinis dalyvavimas (naudojimasis teikiamomis paslaugomis bendruomeneje) yra pasitenkinimo gyvenimu ir geresnio funkcionavimo prielaida. Socialinis dalyvavimas gali pagerinti sveikatą ir sudaryti sąlygas sékmingam senèjimui [10].

Išskiriamos šios socialinès atskirties formos [6]: simbolinè atskirtis, tapatybès (identiteto) atskirtis, sociopolitinè atskirtis, institucinè atskirtis, ekonomine atskirtis, atskirtis nuo reikšmingų ryšių, teritorinè atskirtis. Seni žmonès yra 
linkę patirti atskirti per 5 tarpusavyje susijusias dimensijas: atskirtis nuo materialių resursų, atskirtis nuo socialinių ryšių, atskirtis nuo visuomeninių veiklų, atskirtis nuo bazinių paslaugu ir bendruomeniné atskirtis [6]. Tyrimai rodo [5], kad socialinè atskirtis veikia psichosocialinius, psichologinius, ekonominius, religinius ar dvasinius seno žmogaus gyvenimo aspektus. Tai didina seno asmens psichinị ir emocinį pažeidžiamumą bei daro įtaką seno asmens gyvenimo kokybei [4]. Autorių [5] teigimu, socialinè atskirtis ypač gresia tiems seniems asmenims, kurių amžius yra per $75 \mathrm{~m}$.

Pagrindiniai faktoriai, ịtakūs seno asmens socialinei atskirčiai: ilgalaike liga, su amžiumi susijusios negalios, lètinis skausmas, neseniai įvykusios netektys, sumažèję socialiniai ir šeimos tinklai, ekonominis nuosmukis, susijęs su išèjimu ị pensiją ir sumažejusiomis pajamomis [5].

Daugelis gerontologų senatvès amžiaus tarpsnį ịvardija kaip vaidmenų praradimą [14]. Vaidmenų praradimas mažina subjektyvios gerovés jausmą, o prarastų vaidmenų pakeitimas kitais - didina senų žmonių subjektyvios gerovés jausmą. Subjektyvi gerovè yra sudaryta iš pozityvių ir negatyvių poveikių bei pasitenkinimo gyvenimu. [14]. Viešujų paslaugų prieinamumo didinimas yra vienas iš būdų senų žmonių subjektyvios gerovès jausmui didinti. Šiuo atveju svarbų vaidmenị vaidina socialinè politika: turètų būti vystoma palaikanti ịvarių paslaugų infrastruktūra, bendruomenès įtraukimas ir ryšiai, kurie sumažintų senų žmonių socialinès atskirties jausmą [6]. Pirmas palaikančios viešųų paslaugų infrastruktūos kūrimo etapas - paslaugų prienamumo nustatymas, todèl svarbu išsiaiškinti pagrindinius paslaugų prieinamumą veikiančius veiksnius.

Šio straipsnio tikslas - atskleisti viešujų paslaugų prieinamumą seniems asmenims kaimiškose vietovèse. Šiame tyrime buvo analizuojamas viešujų paslaugų - socialinių paslaugų, susisiekimo ir ryšių paslaugų, sveikatos apsaugos paslaugų - prieinamumas.

\section{Respondentų kontingentas ir tyrimo metodologija}

Siekiant atskleisti viešuju paslaugu prieinamumą seniems asmenims kaimiškose vietovėse buvo naudojami fenomenologinis kokybinio tyrimo tipas, padedantis atskleisti realybę tokią, kokią ją mato tiriamieji.

Tyrime dalyvavo devyni 66 - 89 metų amžiaus asmenys (septynios moterys ir du vyrai), gyvenantys kaimiškose vietovèse. Tyrimo patikimumą lèmé trianguliacijos ir saturacijos principu taikymas. Tyrimo metu buvo taikoma trianguliacija pagal duomenų rinkimo instrumentus. Duomenys buvo renkami naudojant šiuos duomenų rinkimo instrumentus: struktūruotą interviu, stebejimą ir dalyvaujantị stebejjimą. Interviu ir stebejjimus pagal parengtus klausimus atliko Kauno kolegijos Medicinos fakulteto Sociali- nio darbo studiju programos studentès E.Barkauskienė ir V.Bukauskienè. Tyrimo duomenys buvo renkami nuo 2012 m. lapkričio iki $2013 \mathrm{~m}$. balandžio mènesio. Vèliau tyrimo duomenys buvo analizuojami: išskiriami kodai, kategorijos ir analitiniai memai.

Atliekant tyrimą buvo laikomasi tyrimo etikos principų. Tyrimo dalyviams buvo suteikta informacija apie tyrimą ir jie galèjo laisvai apsispręsti dèl dalyvavimo tyrime, nepatiriant jokių negatyvių pasekmių. Visų tyrime dalyvaujančių asmenų vardai buvo keičiami siekiant išsaugoti konfidencialumą.

\section{Rezultatai ir jų aptarimas}

Viešųų paslaugų prieinamumą seniems žmonèms kaimiškose vietovėse apsunkinantys veiksniai.

Subjektyvūs veiksniai, ribojantys viešųjų paslaugų prieinamumą. Atlikus tyrimo duomenų analizę, paaiškèjo šie subjektyvūs veiksniai, ribojantys viešjuju paslaugu prieinamumą: ịvairios tyrimo dalyvių baimès, nežinojimas, kad galima kreiptis pagalbos bei nenoras kreiptis pagalbos.

Interviu metu tyrimo dalyviai išreiškẻ daug ịvairių baimių:

Sakai atvažiuos, neduok Dieve, pas mane važiuos žmogus ir kas nors pasidarys, tai mane prakeiks visi, nenoriu [Agota, 83 metai, interviu].

Viena moteriške bande bendraut su manim, bet jau jai reikejo visko, ka turiu[Valerija, 79 metai, interviu].

Kas dabar daros, kad tik pensijos neatimtu [Jadvyga, 88 metai, interviu].

Iš pateiktų Valerijos ir Jadvygos citatų atsispindi dalyvių baimé netekti savo materialinio turto. Agota, gyvenanti ypač sunkiai geografiškai prieinamoje vietovèje, labai nerimavo dèl žmonių, kurie norètų jai suteikti pagalbą, saugumo. Bijodama dèl kitų asmenų saugumo vykstant pas ją (ypač žiemos periodu) ši tyrimo dalyvè buvo linkusi atsisakyti tiek formalių, tiek neformaliu paslaugų.

Šio tyrimo duomenis patvirtina ir kitų tyrejjų [5] duomenys, kad senų žmonių, ypač moterų, socialinę izoliaciją didina ir baimè. Tai skatina nepasitikejjimą kitais žmonėmis, taip pat nenorą naudotis siūlomomis paslaugomis.

Kiti tyrèjai [7] atliko prognostinị kokybinį tyrimą apie senų žmonių socialinès pagalbos lūkesčius. Minètų tyrèjų duomenimis, senus žmonès labai veikia kiti pavyzdžiai, gaunami iš aplinkinių apie netinkamai teikiamas paslaugas. Seni žmonès išreiškia baimę, kad su jais bus elgiamasi tik kaip su prižiūrimais daiktais, vienetais. Seni žmonès nori būti vertinami kaip unikalūs asmenys, todèl jie pradeda pasitiketi kitais asmenimis, tik kai i juos žvelgiama su pagarba bei paslaugos teikiamos palaikant žmogišką orumą, o svarbiausia - išlaikant ilgalaikius ryšius su paslaugų teikèju [7]. 
Tyrimo dalyvių nežinojimas, kad gali kreiptis pagalbos. Interviu metu tyrimo dalyviai labai dažnai vartojo žodị "nežinau", išreiškiantị informacijos trūkumą apie galimas paslaugas.

Nieka nežinau, kas ty (seniūnijoj) dirba, kas ka dara, nieka nežinau [Anelè, 74 metai, interviu].

O kas čia ka padès? [Jadvyga, 88 metai, interviu].

Tyrimo dalyvių Anelès ir Jadvygos pasisakymuose atsipindi abejonès, ar iš vis galima kokia nors formali ar neformali pagalba.

Gal norètumèt, kad bent karta per savaite pas jus kas nors ateitu? Bet man reikès mokèt iš pensijos? [Agota, 83 metai, interviu]

Tyrime dalyvavusios Agotos interviu ištraukoje įžvelgiamas informacijos apie paslaugų teikimo sąlygas trūkumas. Agota yra ịsitikinusi, kad visos paslaugos mokamos, o mokèti ji nenori. Galima daryti prielaidą, kad apie esamas paslaugas senus žmones pasiekia ir iškreipta, neteisinga informacija, todèl jie ir vengia jomis naudotis.

Kiti tyrèjai [15] pažymi, kad informacija apie paslaugas gali būti pateikta klientams sunkiai suprantama kalba, vartojami sudètingi terminai, tai nulemia klientų nežinojimą apie galimą paslaugų gavimą.

Tyrimo dalyvių nenoras kreiptis pagalbos. Tyrimo duomenų analizė atskleidè labai stiprų senų žmonių vengimą kreiptis pagalbos.

Nenoriu aš list kur nereikia ir vaikščiot ten be reikalo (apie seniūnija) [Jadvyga, 88 metai, interviu].

A Dieve mana buvo visko ale prašyt jau ne, tokia sarmata būtu, jokiu būdu nepaprašyčiau. [Saulè, 77 metai].

Skustis? Aš ne toks žmogus, kad dèl kiekvieno menkniekio skusčiaus [Magdalena, 66 metai, interviu].

Kiek man čia reikia? Sakau (vaikams) sèdèkit, nevažiuokit ir aš sédèsiu [Agota, 83 metai, interviu].

Tyrimo dalyvės Jadvyga ir Saulè nenori prašyti jokios pagalbos. Pagalbos prašymas įvardijimas kaip buvimas ikyriu asmeniu bei gèdingas veiksmas. Magdalena ir Agota pagalbos kreipimąsi suvokia kaip kitų asmenų (giminių ar oficialių paslaugų teikèjų) varginimą, tai joms yra priežastis atsisakyti galimos pagalbos.

Apibendrinant subjektyvius veiksnius, ribojančius viešujų paslaugų prieinamumą, galima daryti prielaidą, kad tyrimo dalyviai siekia kiek ịmanoma ilgiau išsaugoti savo kaip asmens nepriklausomybę nuo kitu.

Objektyvūs veiksniai, ribojantys viešųjų paslaugų prieinamumą. Išanalizavus tyrimo duomenis paaiškejjo tokie objektyvūs veiksniai, ribojantys viešujų paslaugų prieinamumą: gyvenimas geografiškai nepalankioje vietovejje, transporto pasiekiamumo problemos, sveikatos problemos, reikiamų paslaugų trūkumas, lěšų trūkumas.
Gyvenimas geografiškai nepalankioje vietovèje. Visi tyrimo dalyviai gyvena ypač atokiose kaimiškose vietovèse, ịvairios įstaigos gana toli:

Agota gyvena atokiame kaime. Iki artimiausios parduotuvès $4 \mathrm{~km}$., iki seniūnijos centro ir gydytoju - $15 \mathrm{~km}$., iki rajono centro $21 \mathrm{~km}$ [tyrejjų dienoraštis, 2012 lapkričio mèn].

Tyrimo dalyvių amžius nuo 66 iki 89 metų. Kaimiškose vietovėse istaigų tinklas klientams yra sunkiai pasiekiamas. Tyrimo dalyviai patiria teritorinę atskirtį. Ši atskirtis savaime reiškia atskirtị ir nuo bazinių paslaugų.

Transporto problemos. Tyrimo duomenų analizè atskleidè, kad transporto problemos didina senų žmonių izoliaciją kaimiškose vietovèse.

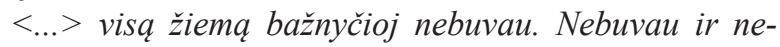
žinau kaip čia prieš tas Velykas nueit, taip šalta, o kojos mano labai bijo šalčio ir neturiu $\mathrm{ka}$ apsiaut. $\mathrm{Nu}$ va taip iš ryto tik 9 valanda galim važiuot, mišios pusę vienuoliktos, turim važiuot anksti, nes autobusai kitaip nevažiuoja, o paskui antra grịžtam, irgi dvi valandas reikia šalti lauke [Jadvyga, 88 metai, interviu.]

Autobusas atvyksta du kartus per diena, žiemos metu dèl stataus, apledejjusio kalno galutinio sustojimo nepasiekia, todèl norint pasiekti stotelę reikia eiti 1,5 km pésčiomis [tyrejjų dienoraštis, 2012].

Blogiausia kai reikia iki daktara, tadu labai blogai žie$m u$, reikia patamsiji ait, kalnas tai slidus, labai slidus. Roza kaip griuvau, tai prasikirtau kaktu, agi šalta, kraujas bèga [Agota, 83 metai, interviu].

Tyrimo dalyviai gyvena geografiškai nepalankioje vietoveje, o tai situaciją dar labiau pablogina. Seniems asmenims kyla labai daug problemų ypač šaltuoju metų periodu, kadangi viešasis transportas važiuoja labai retai.

Kai kurie tyrimo dalyviai reikalingoms paslaugoms pasiekti naudojosi mokykliniais autobusiukais. Vasarą šie autobusiukai nevažiuoja ir kai kuriose kaimiškose vietovėse vasaros metu seni žmonès neturi jokių galimybių pasiekti reikiamas įstaigas:

$<\ldots>$ labai blogai, kaip vasaru vaikai neina mokyklon, autobusas nevažiuoja ir vasaru nèr kuom susisiekt $<\ldots>$ [Anele, 74 metai, interviu].

Tyrimo duomenų analizė atskleidè, kad viešasis trasnportas kaimiškose vietovėse atvažiuoja labai retai ir reikiamų ịstaigų norimu laiku seniems žmonèms pasiekti tampa neįmanoma.

Sveikatos problemos. Prie pirmų dviejų anksčiau minètų nepalankių veiksnių (geografiškai nepalankios gyvenamosios vietos bei transporto problemų) prisideda ir senų žmonių sveikatos problemos.

Šiandie labai nèra tos sveikatos, aš mažai miegu. Kojas 
labai traukia méšlungis, per kauliuka tai tiesiog rodos, kad man kaula sulaužys. Verkiu, tai tiesiog ašaros pačios bèga [Jadvyga, 88 metai, interviu]

Žinai, prabundu ryta ir galvoju, kaip kelsiuos, darysiu ta ir ana. O kai atsikeliu, žiūriu, kad negaliu net be lazdos paeit. Viskas sukas [Ignotas, 89 metai, interviu].

Nežinau, ar galèsiu bent pavasarị i bažnyčia nueit, ar sveikata leis [Valerija, 79 metai].

Sveikata yra savaime labai ribojantis veiksnys bet kokių viešujų paslaugų savarankišką pasiekiamumą ir galimybę jomis pasinaudoti.

Kiti tyrèjai [5] nurodo, kad seni žmonès nenori kreiptis medicininès pagalbos dèl nusivylimo sveikatos priežiūros paslaugomis. Šiuo aspektu seni žmonès save laiko eidžizmo aukomis, nes i jaunus žmones visuomenejje yra labiau kreipiamas dèmesys [5]. Nesikreipiant pagalbos dèl patiriamų sveikatos problemų, žmogaus sveikata tik blogejja ir tokiu būdu dar labiau gilèja socialinè atskirtis, t.y. atsiranda dar didesnè riba gauti viešujų paslaugų.

Ribotos pajamos. Interviu metu tyrimo dalyviai išreiškẻ rūpestị dèl gaunamų pajamų.

Mažai (pinigu), ajetus vaikeli, kompensuoja tris vaistus, a gi ne triju reikia, ir širdies, ir kalio, visko reikia, beveik pusè pensijos išeina [Anele, 74 metai, interviu].

Kaip vasaru, tai keltu ị Čiobiškị ir bažnyčion, ir apsipirkt. Ale labai brangu - 3 litai, anksčiau litas buvo, o dabar labai brangu. Kas čia pasidarè, visiems maža ir maža, labai brangu, vis kelia ir kelia kainas[Agota, 83 metai, interviu].

Šiaip taip pakol kas užtenka, o kaip toliau nežinia, labai jau vaistai brangūs, viskas brangu [Milda, 76 metai, interviu].

Vajetau tu mana. Mana be 3 litu 600, jo (vyro) 700, ale mes kaip dvejuose, da ni geriam, ni rūkam, tai mum ir užtenka, ale kap liksi vienas ir pragyvenk, o jeigu teip tai sunku būtų.Pasitaupai, neišleidi ir užtenka [Saulè, 77 metai, interviu].

Tyrimo dalyvių gaunamos pensijos pakanka tik pagrindiniams poreikiams patenkinti, visi tyrimo dalyviai yra priversti taupyti. Tyrime dalyvavę asmenys išreiškia nerimą, kad augant kainoms, ateityje gali neužtekti pajamų savo poreikiams patenkinti.

Reikiamų paslaugų trūkumas. Tyrimo duomenų analizè atskleidè, kad seniems asmenims, gyvenantiems kaimiškose vietovėse, ypač reikalingos bendravimo paslaugos. Pateiktose interviu ištraukose atsispindi tyrimo dalyvių patiriamas vienišumo jausmas.

Niekas, niekas, niekas iš seniūnijos nelanka, jokiu pašalpu, nieka negaunu, niekas nelanka [Anelè, 74 metai, interviu]
Visada buvau tarp žmoniu. Vakare atsiguli vienas, toks vienas. Tai gerai, kad šitas draugas yra (rodo ị televizoriu). Isivaizduok, visa diena sédi ir sédi. Nu, dar kol malku atne$\check{s i}$ i, dar pagastroliauji [Ignotas, 89 metai, interviu].

Labai liūdna vienai, dangiausia vakarais. Pabūtum tiek viena, kiek aš ir tu atprastum kalbèt. Nebuvau tokia [Valet rija, 79 metai, interviu].

Tyrime dalyvavusiems seniems asmenims ypač trūksta bendravimo, ilgalaikių socialinių ryšių su kitais asmenimis.

Vienišumas apbrěžiamas kaip subjektyvi negatyvi patirtis, o socialinè izoliacija - neturejjimas ryšiu su kitais asmenimis, o tai traktuojama kaip rimta senų žmonių problema [3]. Tyrimais nustatyta, kad apie $40-50$ proc. 80 metų asmenų yra visiškai vieniši. Gali būti išskiriamas socialinis ir emocinis vienišumas [9]. Socialinis vienišumas reiškia asmens socialinès integracijos trūkumą. Emocinis vienišumas reiškia prisirišimo nebuvimą su kitais. Užsienio šalių autoriai [7] teigia, kad kai nèra nieko artimo, yra lengva pasijusti paliktam, niekam nereikalingam. Tie patys autoriai pažymi, kad seniems žmonėms ypač svarbu turèti artimų socialinių ryšių. Seni žmonės nori, kad jiems teiktų paslaugas tokie asmenys, kurie juos pažinotų, žinotų jų gyvenimo istoriją.

Viešųjų paslaugų prieinamumą seniems žmonėms kaimiškose vietovèse palengvinantys veiksniai. Išnalizavus interviu duomenis paaiškèjo, kad seniems vienišiems žmonèms būdingas noras kiek įmanoma ilgiau pasirūpinti savimi pačiam. Labiausiai paslaugų prieinamumą palengvina kaimynų, giminių (vaikų) pagalba bei neformali savanoriška specialistų pagalba.

Asmens motyvacija pasirūpinti savimi (noras nuo kitų nepriklausyti). Tyrimo duomenys atskleide, kad seni žmonès siekia kiek įmanoma ilgiau išsaugoti savo gerą funkcionavimą:

Viska pati: ir patalyni, viska pati išsiplaunu, tik dabar skalbimo mašina sugedus. Ateina jie (kaimynai), vis klausia, gal ku padèt, ale kad man nieka nereikia, aš visku pati pasidarau, kiek man reikia [Agota, 83 metai, interviu].

Aš viska pati išsiskalbiu ir viska pati pasidarau, neduodu joms (dukroms) [Anelè, 74 metai, interviu].

Viska dirbu ir išplaunu, ir sutvarkau, tai grindys, tai kambarius ar kokiq užuolaida, viska dirbu ka reikia [Jadvyga, 88 metai, interviu].

Asmens motyvaciją pasirūpinti savimi galima įvardinti kaip norą nepriklausyti nuo kitų. Laisvè ir nepriklausomybė moderniose Vakarų kultūrose yra traktuojama kaip asmens teisè priimti nepriklausomus sprendimus [7]. Žmogiškumas apima ir suponuoja individo laisvę ir teises. Žmogiškumas igyvendinamas per santykius su kitais žmonemis ir konkrečiose situacijose, ten, kur kas nors vyksta [12]. 
Tyrimo dalyvès Agota, Anelè ir Jadvyga pažymi kaip svarbu joms savarankiškai atlikti visus būtinus darbus, kad tik nereikètų prašyti kitų žmonių pagalbos. Šio tyrimo duomenys atskleide, kad seni asmenys taip pat siekia kiek įmanoma savarankiškai pasiekti ịvairias paslaugas:

$<\ldots>$ reikia patamsiji ait, kalnas tai slidus, labai slidus, aš jau tep mikliai neinu, tai aš šeštu valandu ir išeinu, patamsiji, taip kaip rozas autobusas pusę septyniu [Agota, 83 metai, interviu].

Taigi, paslaugu prieinamumą padidina asmens ryžtas siekti paslaugų. Iš pateiktų citatų atsiskleidžia tyrimo dalyvių baimè tapti nereikalingiems, nenaudingiems, jei reiktų prašyti kitų asmenų pagalbos.

Vis tik kiti tyrejai pabrèžia, kad laisvè ir nepriklausomybè tuo pačiu metu gali reikšti teigiamus ir neigiamus dalykus: kai stengiamasi būti nepriklausomam, yra tikimybè tapti izoliuotam ir vienišam [7].

Kai kurie šio tyrimo dalyviai visiškai nepriimdami reikiamos pagalbos iš kitų rizikuoja labai apriboti savo socialinius kontaktus.

Kaimynai: savanoriška ir samdoma pagalba. Gera kaiminystè sudaro prielaidas padèti vieni kitiems [13]. Kaimiškose vietovèse būdingi stipresni socialiniai ryšiai ir tai gali būti panaudojamas kaip resursas, kai silpnesni bendruomenès nariai yra paremiami ir globojami kitų narių ar teikiama bendruomenès pagalba asmeniui, esančiam nepalankiose gyvenimo aplinkybėse [11].

Kaimynystė yra neformalios institucijos pavyzdys, kuri turi savo taisykles ir vienų žmonių su kitais kontaktų struktūrą. Kaimynai žino vieni apie kitus daug informacijos, dalị gyvenimo istorijos. Kaimynai gali padaryti vieni kitiems gyvenimą malonų, padėdami vieni kitiems, arba atvirkščiai - kurdami problematiškus santykius. Kaimyniniai ryšiai yra laikomi labai svarbūs, nes jie netiesiogiai pozityviai veikia socialinę ir fizinę vietinès aplinkos kokybę, nes kaiminystès kontaktai stimuliuoja vietinị dalyvavimą [13].

Neformali savanoriška kaimynų pagalba. Tyrimo dalyvè Agota atskleidžia, kad kaimynai savanoriškai suteikia konkrečią (instrumentinę) pagalbą ligos atveju:

Buvau vienus metus metus apsirgus, tai da čia kaimynai gyvena, tai mergiotès ateidavo, pečiu pakūrendavo, malku, vandens atnešdava, teip ir prasirgau [Agota, 83 metai, interviu].

Kitai tyrimo dalyvei Magdalenai iki šiol neteko priimti kaimynų pagalbos, tačiau ji tiki, kad kaimynai geranoriškai padètų:

Santykiai su kaimynais geri. Ir vandens atneštu, ir valgyt, ne bèda. Ne vienas, tai kitas kaimynas pagelbètu [Magdalena, 66 metai, interviu].

Skirtingai nei Agota ir Magdalena, tyrimo dalyvė Vale- rija pabrěžia ne konkrečios pagalbos iš kaimynų svarbą, o nekonkrečios - aplankymo, diskusijų. Iš Valerijos interviu ištraukos atsispindi labai stiprus, pasitikèjimu grindžiamas ryšys su kaimyne:

Kaimyne gera turiu. Ateina, padeda ka reikia, pakalbam. Isivaizduok, atsikeliu šešta, pasimeldžiu, tada septinta ateina kaimynè. Išgeriam arbatos, suvalgom sumuštini, pakalbam [Valerija, 79 metai, interviu].

Kaimyno paprašau ir man vaistus parveža. O kai reikia, tai paveža rajonan. Jis dirba rajone, tai kasdien važiuoja. [Anelè, 74 metai, interviu].

Galima daryti prielaidą, kad neformali savanoriška kaimynų pagalba išsprendžia daugelị senų žmonių, gyvenančių kaimiškose vietovėse, problemų, t.y. užpildo spragą tarp oficialių paslaugų trūkumo. Taigi, galima teigti, kad kaiminystès kontaktai stimuliuoja senų žmonių vietinį dalyvavimą kaimo bendruomeneje ir mažina socialinès atskirties riziką.

Samdoma kaimynų pagalba. Tyrimo duomenų analizè atskleidè, kad ne visa kaimynų teikiama pagalba yra savanoriška. Tyrimo dalyvès mini, kad už kai kurias paslaugas kaimynams užmoka:

Ar galite surasti žmogu, kad padètu nukasti sniega iki kelio? O, galima laisvai. Tik ne šiandien, nes visi girti. Sniega kasti reikia, kai pašalpu nemoka [Magdalena, 66 metai, interviu].

O kas padeda žemę sutvarkyti, daržus pasisodinti? Kaimynès sūnus paaria, kitas kaimynas užsakau méšla atveža, tai aš sumoku, niekas nesaka, kad už ačiū, svarbu, kad gavai [Anelè, 74 metai].

Šiemet kaimynas atvežè trejas rogelas (malku). Rogela 40 litu, tai 120 sumokejjau [Agota, 83 metai, interviu].

Iš pateiktų citatų atsiskleidžia, kad tyrimo dalyvès yra apgalvojusios, kas kokią mokamą pagalbą galètų suteikti. Tai atskleidžia ir organizacinius senų žmonių, gyvenančių kaimiškose vietovèse, gebejjimus.

Giminių (vaikų) pagalba. Giminių (vaikų) pagalba palengvina paslaugų prieinamumą seniems asmenims visais požiūriais: ir finansiniu, ir geografiniu, ir transporto:

Jüratè, tai kai nedirba, tai čia ir čia. I savaitę viena karta, kartais ir du atvažiuoja, kaip jai išeina. Maisto priveža, kad mamka nebadautu [Magdalena, 66 metai, interviu].

Aplanko, negaliu sakyt, kaip sveiki anūkai atvažiuoja. Va ir praeitu šeštadieni atvažiava, tai sūnus malku papjovè, negaliu skūstis, vasara tai išvis dažnai atvažiuoja [Milda, 76 metai, interviu].

A vo, malkas visas suskalda ir sukrauna, va sirgau, tai malkas sutvarke ir maista atveža. Aš tai va tokiose aftolafkèse neinu maista laukt, man Kaunas atveža visa laika, nenoriu, kad ačiū, ale kiek aš ty sumoku (juokiasi) [Anelè, 74 metai, interviu]. 
Tyrimo dalyvių vaikai ypač rūpinosi savo tėvais: užregistruodavo ir nuveždavo pas reikiamus sveikatos priežiūros specialistus, aprūpindavo maistu ir kt. gyvenimui reikalingais dalykais, taip pat suteikdavo ir finansinę paramą. Jei ne tyrimo dalyvių suaugusių vaikų pagalba - paslaugų prieinamumas seniems asmenims būtų daug sudètingesnis ir sunkesnis.

Rytų Europos valstybèse yra polinkis remtis giminių ar vaikų pagalba prižiūrint senus žmones [2]. Priešingai yra Vakarų Europos valstybėse, kur nesitikima pagalbos iš užaugintų vaikų [7]. Šiame tyrime vienos dalyvès pasisakymas apie galimą pagalbą iš savo dukterų ateityje buvo netipiškas:

<...>jei kadu visai negalèsiu, tai sakiau jom (dukrom), kad gali mani atiduot slaugot ar seneliu namuosna, kad tik neatsisakytu darbo del many, bo jom da gyvent ir gyvent, a man vis tiek jau viskas <..> [Anelè, 74 m., interviu].

Pateikta citata rodo Anelès norą, kad dukros gyventu savo nepriklausomą gyvenimą ir nesiaukotų dèl jos. Anelei yra priimtina tai, kad dukros surastų tinkamus slaugos ar senelių namus, jei ji pati negalètų pasirūpinti savimi.

Vis tik dauguma tyrimo dalyvių buvo tokių, kurie laukè ir sulauke iš savo vaikų ir anūkų realios pagalbos.

Tyrimo duomenų analizė atskleidè, kad daug sunkiau yra tiems seniems asmenims, kurių vaikai (giminès) gyvena toli, negali dažnai aplankyti savo tèvų ir ryšys yra palaikomas tik telefonu. Taip pat tarp tyrimo dalyvių buvo ir tokių senų žmonių, kurių giminès (vaikai) emigravę ar jų iš vis tiesiog nèra. Pažymètina, kad šiems asmenims buvo sunkiausiai pasiekiamos ịvairios paslaugos.

Neformali savanoriška specialistų pagalba. Tyrimo duomenys atskleide, kad kaimo vietovèse dirbantys specialistai dažnai atlieka ne tik tas funkcijas, kurios priklauso pagal pareigines nuostatas (instrukcijas) bet ir tas, kurios neįeina i jų pareigas.

Nu kap pasiekiu daktara? Važiuoja laiškanešè, tai iš vakara paskambiju, tai ji many paiima, jeigu suspejju, tai ir parveža, ar kadu ir palaukia, labai geras žmogus, čia aptarnauja iš Z. kaimo. O vaistus, tai socialinès paprašau ir parveža [Magdalena, 66 metai, interviu].

A dabar niekas neateina, ateina tik paštininkè, tai jai už telefona, elektra sumoku ir dar toji kur pensijas vežioja, daugiau niekas. Paštininkę tai jau senai pažistu, mes pasikalbam apie viska [Agota, 83 metai, interviu].

Iš pateiktų citatų atsiskleidžia, kad specialistai savanoriškai suteikia pavèžèjimo, bendravimo, tarpininkavimo paslaugas. Pareigų, neįeinančių i̇ pareigines instrukcijas, atlikimą, galima būtų įvardinti kaip sąmoningai pasirinktą savanorystę, siekiant pagelbèti seniems žmonèms, gyvenantiems atokiose kaimiškose vietovèse. Savanoriškumas pasireiškia specialistų gera valia, atliekant darbus be jokio užmokesčio.

\section{Išvados}

Kokybinio fenomenologinio - etnografinio tyrimo radiniai atskleidè, kad viešųų paslaugų prieinamumą apriboja objektyvūs (sveikatos problemos, reikiamų paslaugų trūkumas, lěšų trūkumas reikiamoms paslaugoms, transporto pasiekiamumo problemos, gyvenimas geografiškai nepalankioje vietovejje) ir subjektyvūs (ịvairios baimès, nežinojimas, kad galima kreiptis ir gauti pagalbą, nenoras kreiptis dèl pagalbos) veiksniai.

Viešujų paslaugų prieinamumą seniems vienišiems asmenims, gyvenantiems kaimiškose vietovèse, palengvina neformali savanoriška kaimynų pagalba, samdoma pagalba, giminių (vaikų) pagalba, neformali savanoriška specialistų pagalba, oficialių institucijų dèmesys bei asmens motyvacija pasirūpinti savimi.

\section{Literatūra}

1. Atkočiūnienė V. Kaimo vietovès pokyčių valdymas pagal principą "iš apačios ị viršų". Ekonomika ir vadyba: aktualijos ir perspektyvos. 2008; 2 (11): $50-62$.

2. Bodi DC. Role of the family and of the social services in elderly persons' life. Bulletin of the Trasilvania University of Braşov. 2009; 51(2):137-144.

3. Boeckxstaens P, De Graaf P. Primary care and care for older persons: Position Paper of the European Forum for Primary Care. Quality in Primary Care 2011;19:369-89.

4. Cloutier-Fisher D, Kobayashi K, Smith A. The subjective dimension of social isolation: A qualitative investigation of older adults' experiences in small social support networks. Journal of Aging Studies; 2011; 4(25):407-414.

5. Greaves M, and Rogers-Clark C. 'Once I became a pensioner I became a nobody - a non-entity': The story of one woman's experience of the health care system. Contemporary Nurse, 2011, 37(2): 204-212.

6. Grenier AM and Guberman M. Creating and sustaining disadvantage: The relevance of a social exclusion framework. Health and Social Care in the Community, 2009; 17 (2): 116-124.

7. Harreforts Ch., Sävenstedt S, Axelsson. Elderly people's perception of how they want to be cared for: an interview study with healthy elderly couples in Northern Sweden. Scandinavian Journal of Caring Sciences. 2009; Vol. 2(23):353-360.

8. Hawton A., ir kt. The impact of social isolation on the health status and health-related quality of life of older people. Quality Life Research 2011; 20:57-67.

9. Heylen L. The older, the lonelier? Risk factors for social loneliness in old age. Ageing \& Society; 2010; 7(30):1177-1196,20.

10. Hsu H C. Does social participation by the elderly reduce mor- 
tality and cognitive impairment? Ageing \& Mental Health. 2007; 6(11):699-707.

11. Humble M. et al. Challenges in rural social work practice: when support groups contain your neighbours, church members, and the PTA. Social Work with Groups. 2013; 2/3(36):249-258,10.

12. Lies Gualthérie van Weezel ir kt. Mąstyti, veikti, būti: socialinis darbas organizacijoje. Lietuvos socialinių darbuotojų asociacija, 2010.

13. Mollenhorst G, Völker B \& Schutjens V. Neighbour relations in the Netherlands - a decade of evidence. Tijdschrift voor Economische en Sociale Geografie, 2009; (4)100:549-558.

14. Nakahara Jun. Effects of social activities outside the home on life satisfaction among elderly people living alone.International Journal of Psychological Studies. 2013; Vol. 1(5):112-120.

15. Stockwell -Smith G, Kellet U, Moyle W. Why carers of frail older people are not using available respite services: an Australian study. Journal of Clinical Nursing, 2010; 19: 2057 -2064.

16. Viešujų paslaugų vartotojų pasitenkinimo indekso apskaičiavimo metodika. LR vidaus reikalų ministerija. Viešojo valdymo politikos departamentas, Vilnius, 2010.

THE ACCESSIBILITY OF PUBLIC SERVICES TO OLD

\section{PEOPLE IN RURAL AREA}

A. Kavaliauskienė, I. Skridlaitė

Key words: old people, rural area, public servicives, the accessibility.

Summary

Many countries encounter a demographic change where the numer of elderly people will increase. As a result, the number of very old people needing various services [7]. The population in Lithuanian rural areas (communities) is ageing very fast.The need of various services in local community is increasing by ageing population [15].
Public Service, as defined in the Law on Public Administration of the Republic of Lithuania, encompasses all the activities of legal persons, controlled by the state or municipalities, when providing social services for persons, as well as services in the spheres of education, science, culture, sports and other services provided for by laws. Other people may also provide public services in the cases and in the manner provided for by law [16].

The research reveals that elderly people are experiencing social exclusion (isolation). The social policy has important role that lead to the development of supportive infrastructure, community engagement and intimate relationships that reduce feelings of exclusion [5]. The first stage of creation of supportive public services infrastructure is the determination of service accessibility. It is important to clarify the main factors influencing the accessibility of services.

The aim of this article is to reveal the accessibility of public services in rural areas for elderly people. By using qualitative research method there was analized the accessibility of these public services: social services, transport services and health services. By the research was discovered that the accessibility of public services to elderly people in rural areas restrains objective (health problems, lack of needed services, lack of money for needed services, access to public transport, living in disadvantaged rural area) and subjective (various fears, lack of knowledge about possible help, resistance to ask for help) factors. The accessibility of public services for elderly people in rural areas facilitates informal support of neighbours and relative (children), informal voluntary support of specialists. The elderly people were wanting and very motivated to take care about themselfs. This factor also facilitate the accessibility of public services.

Correspondence to: ausra.kavaliauskiene@go.kauko.lt

2013-07-08 